\title{
METODE YANBU'A DALAM PENANAMAN KEMAMPUAN MEMBACA HURUF HIJAIYAH PADA SANTRI TPQ AT-TAUHID TUBAN
}

\author{
Aya Mamlu'ah' \\ Devy Eka Diantika ${ }^{2}$ \\ IAI Sunan Giri Bojonegoro \\ Ayytusfa@yahoo.com
}

\begin{abstract}
Abstrak
Penanaman kemampuan membaca Huruf Hijaiyah merupakan suatu hal yang sudah lazim bagi Taman Pendidikan Al-Qur'an. Masalah pokok yang sering dihadapi oleh santri TPQ di Taman Pendidikan Al-Qur'an di wilayah kecamatan Senori adalah metode yang digunakan dalam kemampuan membaca huruf hijaiyah. Latar belakang dari pada penulisan ini adalah ditemukan para santri yang berusia 3 tahun yang mengikuti proses pembelajaran mengaji di TPQ At-Tauhid Leran Senori Tuban. Penelitian ini merupakan penelitian tindakan kelas (PTK) yang bersifat kualitatif, dengan mengambil lokasi di TPQ At-Tauhid Leran Senori Tuban. Pengumpulan data dilakukan dengan wawancara, observasi dan dokumentasi, analisis data dilakukan dengan memberikan makna terhadap data yang berhasil dikumpulkan dan dari makna itu ditarik kesimpulan.hasil dari penerapan metode yanbu'amenunjukan peningkatan signifikan yaitu pada kemampuan membaca yang awalnya $43 \%$ naik menjadi 55\% pada siklus I dan menjadi $75 \%$ pada Siklus II. Dengan demikian metode yanbu'a dapat menanamkan kemampuan membaca huruf hijaiyah pada santri di TPQ At-Tauhid Leran Senori Tuban.
\end{abstract}

Kata Kunci : metode yanbu'a, penanaman kemampuan membaca huruf hijaiyah

\section{Abstract}

Planting the ability to read Hijaiyah letters is a common thing for the Al-Qur'an Education Park. The main problem often faced by TPQ students in the Al-Qur'an Education Park in the Senori sub-district is the method used in the ability to read hijaiyah letters. The background of this writing is that the 3-year-old santri who followed the learning process of reciting in the TPQ At-Tauhid Leran Senori Tuban. This research is a qualitative classroom action research (PTK), taking location in At-Tauhid Leran TPQ Senori Tuban. Data collection is done by interviewing, observing and documenting, data analysis is done by giving meaning to the data that has been collected and from that meaning drawn conclusions. The results of the application of the Yanbu'am method show a significant increase in reading ability which initially $43 \%$ rose to $55 \%$ in cycle I and become $75 \%$ in Cycle II. Thus the method of yanbu'a can instill the ability to read hijaiyah letters in santri at TPQ At-Tauhid Leran Senori Tuban.

Keywords : yanbu'a method, planting the ability to read the letters hijaiyah 


\section{PENDAHULUAN}

Penanaman kemampuan membaca Huruf Hijaiyah merupakan suatu hal yang sudah lazim bagi Taman Pendidikan Al-Qur'an. Masalah pokok yang sering dihadapi oleh santri TPQ di Taman Pendidikan Al-Qur'an di wilayah kecamatan Senori adalah metode yang digunakan dalam kemampuan membaca huruf hijaiyah. Hal ini ditandai dengan indikasi seperti: (a) lemahnya santri di dalan mengenal huruf hijaiyah, (b) kesulitan santri dalam membedakan huruf hijaiyah tertentu (contoh tsa-sa, dha-dza), (c) santri kesulitan dalam membedakan panjang pendeknya harokat/tanda baca.

Lemahnya kemampuan membaca huruf hijaiyah telah banyak diteliti oleh para peneliti sebelumnya. Hal ini menunjukan bahwa problem tersebut masih actual untuk diangkat pada saat ini. Dari sekian banyak penelitian yang ada, dua diantaranya yang dianggap relevan dengan penelitian ini: (1) penelitian yang dilakukan oleh Heni Kurniawati dengan judul 'efektivitas Metode Yanbu'a dalam pembelajaran Al-Qur'an di TPQ Tarminatussibyan Karangrandu Pecangaan Jepara” (2) penelitian yang dilakukan oleh Fitri Rahmawati dengan judul "Penerapan Metode Yanbu'a dalam Pembelajaran Baca Tulis Al-Qur'an di Taman Pendidikan Al-Qur'an Husnut Tilawah Payaman Mejobo Kudus.

Pembelajaran Al-Qur'an pada saat ini masih ada yang berupa klasikal, berhasil tidaknya suatu pembelajaran ditentukan oleh metode pembelajaran yang merupakan bagian integral dalam sistem pembelajaran. ${ }^{1}$ Berdasarkan penjelasan tersebut dapat dipahami bahwa penyebab utama kurang berhasilnya pembelajaran membaca Al-Qur'an khususnya kelancaran dan kefasihan baca adalah pembelajaran yang masih klasikal yang mana pembelajaranberpusat pada guru dan santri yang masih belum berperan aktif dalam pembelajaran.

Secara khusus Flood dan Laap, mengidentifikasi tahapan perkembangan kemampuan membaca pada anak, yakni;

1. Tahap fantasi (magical stage); pada tahap ini anak mulai menggunakan buku, mulai berpikir bahwa buku ini penting, melihat atau membolak-balikan dan kadang-kadang anak membawa buku kesukaannya. Pada tahap pertama orangtua atau guru dapat memberikan atau menunjukkan model/contoh tentang perlunya membaca, membacakan sesuatu pada anak, membicarakan buku pada anak.

2. Tahap pembentukan konsep diri (self concept stage); pada tahap kedua orangtua atau guru memberikan rangsangan dengan jalan membacakan sesuatu pada bukubuku yang diketahui anak-anak. Orang tua atau guru juga hendaknya melibatkan anak membacakan berbagai buku.

\footnotetext{
${ }^{1}$ Hafidz Abdurrahman, Ulumul Qur'an Praktis-Metode Memahami Al-Qur'an, (Bogor:Idea Pustaka Utama 2003) Hlm. 15.
} 
3. Tahap membaca gambar (bridging reading stage); pada tahap ketiga, orang tua atau guru membacakan sesuatu kepada anak-anak, menghadirkan berbagai kosa kata pada lagu dan puisi dan memberikan kesempatan menulis sesering mungkin.

4. Tahap pengenalan bacaan (take of reader stage); pada tahap keempat orang tua atau guru masih harus membacakan sesuatu untuk anak-anak sehingga mendorong anak membaca sesuatu pada berbagai situasi. Orang tua atau guru jangan memaksa anak membaca huruf secara sempurna.

5. Tahap membaca lancar (independent reader stage); pada tahap ini, orang tua atau guru tetap membacakan berbagai jenis buku pada anak-anak. Tindakan ini mendorong anak agar dapat memperbaiki bacaannya.membantu menyeleksi bukubuku bacaan yang sesuai serta mengajarkan cerita yang berstruktur. ${ }^{2}$

Kemampuan membaca juga melalui berbagai tahapan-tahapan sehingga anak mampu untuk membaca secara lancar begitupun pula permasalahan lain dalam membaca huruf hijaiyah yaitu siswa kurang memahami tajwid, yaitu tentang kaidah hukum bacaan, waqof danlain-lain. Hal ini senada dengan penuturan Zakiyah Drajat yaitu membaca Al-Qur'an harus menggunakan tajwid yaitu suatu ilmu yang membicarakan pengaturan-pengaturan dan cara membaca Al-Qur'an dan memanjangkan yang harus dibaca panjang dan memendekkan yang harus dibaca pendek. ${ }^{3}$

Dengan adanya problematika-problematika yang berkembang saat ini tentang pembelajaran Al-Qur'an yang mana menitik beratkan pada kefasihan dan kelancaran baca santri maka diperlukan metode pembelajaran yang dapat mengatasi masalah-masalah tersebut yaitu: (1) Pembelajaran yang mengharuskan santri berperan aktif. Maksudnya, dalam pembelajaran santri memperoleh pengalaman secara nyata, sehingga santri termotivasi dengan sendirinya untuk mengikuti dan berperan aktif dalam pembelajaran. (2) Penggunaan metode dan media yang tepat sehingga pembelajaran dapat berlangsung secara efektif dan efesien walaupun waktu yang tersedia terbatas. (3) Dalam memilih pengajar lembaga haruslah memilih orang-orang yang berpengalaman dan professional, selain itu pengajar haruslah menciptakan situasi dan kondisi yang memungkinkan terjadinya proses belajar yang efektif dan efesien bagi anak didik. ${ }^{4}$

Melihat keadaan santri TPQ At-Tauhid yang mana kettika menginjak usia 3 tahun para orang tua sudah mendaftarkan anaknya untuk mengikuti kegiatan belajar mengajar, yang mana pada usia tersebut sering kali ditemukan kesulitan-kesulitan yang dihadapi oleh guru dalam memghadapi anak pada usia tersebut, sehinnga peneliti tertarik dalam pelaksanaan pembelajaran mengaji yang berada di TPQ tersebu.

\footnotetext{
${ }^{2}$ Samso Samudaya, Strategi dan Teknik Pembelajaran Membaca, (Yogyakarta: Graha Ilmu, 2011) Hlm 12

${ }^{3}$ Zakiyah Drajat, Ilmu Pendidikan Islam, (Jakarta:Bumi Aksara,1996) Hlm 13.

${ }^{4}$ St. Venbriyanto dkk, Kamus Pendidikan, (Jakarta: Grafindo, 1996) Hlm. 45.
} 


\section{METODE YANBU'A}

Metode yanbu'a adalah suatu metode baca tulis dan menghafal Al-Qur'an, untuk membacanya santri tidak boleh mengeja, membaca langsung dengan cepat, tepat, lancar dan tidak putus-putus disesuaikan dengan kaidah makharijul huruf. Timbulnya "Yanbu'a" adalah usulan dan dorongan Alumni Pondok Tahfidh Yanbu'ul Qur'an, supaya mereka selalu ada hubungan dengan pondok disamping usulan dari masyarakat luas juga dari lembaga pendidikan Ma'arif serta Muslimat terutama dari cabang kudus dan Jepara. ${ }^{5}$

Penyusuan Metode Yanbu'a diprakarsai oleh tiga tokoh pengasuh Pondok Tahfidh Yanbu'ul Qur'an putra KH. Arwani Amin Al-Kudsy (Alm) yang bernama: KH. M. Ulin Nuha Arwani, KH. Ulil Albab Arwani dan KH. Manshur Maskan (Alm) dan tokoh lain diantaranya: KH. Sya'roni Ahmadi (Kudus), dan KH. Amin Sholeh (Jepara), Ma'mun Muzayyin (Kajen Pati), KH. Sirojuddin (Kudus) dan KH. Busyro (Kudus) beliau adalah Mutakhorrijin Pondok Tahfidh Yanbu'ul Qur'an yang tergabung dalam majelis "Nuzulis Sakinah" Kudus.

Cara pembelajaran Yanbu'a yaitu (1) Musyafahah yaitu guru membaca terlebih dahulu kemudian santri menirukan. Dengan cara ini guru dapat menerapkan membaca huruf dengan benar melalui lidahnya. Sedangkan santri akan dapat melihat dan menyaksikan langsung praktek keluarnya huruf dari lidah guru yang ditirukannya. (2) Ardhul Qira'ah yaitu santri membaca di depan guru sedangkan guru menyimak dengan baik. Sering juga cara ini disebut dengan sorogan. Dengan cara ini akan memudahkan guru untuk mengetahui dan membenarkan bacaan santri yang keliru. (3) Pengulangan yaitu guru mengulang-ilang bacaan, sedangkan santri menirukannya kata per kata atau kalimat per kalimat, juga secara berulang-ulang hingga terampil dan benar. ${ }^{6}$

Dari berbagai sistem penyampaian materi belajar Al-Qur'an yang ada saat ini, semuanya mengedepankan penyampaian materi belajar yang memudahkan siswa dalam menerima pesan pembelajaran, khususnya pembelajaran Al-Qur'an. Akan tetapi kebanyakan lembaga pendidikan Al-Qur'an yang ada tidak meninggalkan teori musyafahah sebagai sistem paling bagus dalam mencapai hasil yang maksimal. Hal ini tidak lepas dari penyampaian materi yang begitu simple yakni siswa menirukan secara langsung apa-apa yang dibaca oleh guru secara perlahan melalui lidahnya, kemudian guru juga dapat mengoreksi secara langsung baik makharijul huru, tajwid atau lainya, sehingga siswa dapat secara benar membaca Al-Qur'an.

\footnotetext{
${ }^{5}$ M. Ulin Nuha Arwani, Thariqh Baca Tulis dan Menghafal Al-Qur'an Yanbu'a Bimbingan cara mengajar, (Kudus: Pondok Tahfidh Ynbu'ul Qur'an Kudus, 2009) Hlm 1.

${ }^{6}$ M. Ulin Nuha Arwani, Thariqh Baca Tulis dan Menghafal Al-Qur'an Yanbu'a Bimbingan cara mengajar, (Kudus: Pondok Tahfidh Ynbu'ul Qur'an Kudus, 2009) Hlm 2.
} 


\section{METODE PENELITIAN}

Desain penelitian ini adalah penelitian tindakan kelas (Classroom Action Research). Penelitian tindakan kelas meruapakan suatu pencermatan terhadap kegiatan belajar berupa sebuah tindakan, yang sengaja dimunculkan dan terjadi dalam sebuah kelas. Tindakan tersebut diberikan oleh guru atau arahan dari guru yang dilakukan oleh siswa. ${ }^{7}$ Dalam melakukan penelitian ini, peneliti menggunakan pendekatan kualitatif. Seorang ahli penelitian bernama McNIFF dengan tegas mengatakan bahwa penelitian tindakan kelas merupakan bentuk penelitian reflekstif yang dilakukan oleh guru sendiri yang hasilnya dapat dimanfaatkan sebagai alat untuk pengembangan dan perbaikan pembelajaran. Dengan penelitian tindakan kelas guru dapat meneliti sendiri terhadap praktik pembelajaran yang dilakukannya di kelas. Guru dapat melakukan penelitian terhadap siswa dilihat dari aspek interaksinya dalam proses pembelajaran. ${ }^{8}$

Desain penelitian tindakan kelas ini menggunakan model John Elliot yang terdiri atas 4 komponen penelitian tindakan yaitu : (1) Perencanaan, pada komponen ini guru sebagai peneliti merumuskan rencana tindakan yang akan dilakukan untuk memperbaiki dan meningkatkan proses pembelajaran, perilaku, sikap dan prestasi belajar siswa. (2) Tindakan (Action) pada komponen ini, guru melaksanakan tindakan, berdasarkan rencana tindakan yang direncanakan, sebagai upaya perbaikan dan peningkatan atau perubahan proses pembelajaran, perilaku, sikap dan prestasi belajar siswa yang diinginkan. (3) Pengamatan (Observasi) pada komponen ini, guru mengamati dampak atau hasil dari tindakan yang dilaksanakan atau dikenakan pada siswa. Apakah berdasarkan tindakan yang dilaksanakan tersebut member pengaruh yang meyakinkan terhadap perbaikan dan peningkatan proses pembelajaran dan hasil belajar siswa atau tidak. (4) Refleksi (Reflection) pada komponen ini guru mengkaji dan mempertimbangkan secara mendalam tetang hasil atau dampak dari tindakan yang dilaksanakan itu dengan mendasarkan pada berbagai criteria yang telah dibuat. Berdasarkan hasil refleksi ini, guru dapat melakukan perbaikan terhadap rencana awal yang telah dibuatnya jika masih dapat keurangan sehinngga belum memberikan dampakperbaikan dan peningkatan yang meyakinkan.

Subyek penelitian pada penelitian ini adalah santri di TPQ At-Tauhid Leran Senori Tuban pada Yanbu'a Jilid Pemula dan Yanbu'a Jilid 1 Semester Ganjil Tahun Pelaharan 2018/2019. Jumlah santri keseluruhan 33 terdiri dari 20 santri laki-laki dan 13 santri perempuan.

Penelitian ini dilakukan sebanyak dua siklus selama dua bulan yakni Oktober dan November 2018. Setiap siklus dilaksanakan dalam tiga kali pertemuan. Perencaan ini mempertimbangkan bahwa mengingat dilakukan di TPQ, peneliti setiap hari melakukan tatap muka dengan anak-anak pada kelas yang sama, maka waktu dua bulan dianggap

\footnotetext{
${ }^{7}$ Suharsismi Arikunto, dkk, Penelitian Tindakan Kelas, (Jakarta: PT. Bumi Aksara, 2007) Hlm. 3.

${ }^{8}$ Mohammad Asrori, Penelitian Tindakan Kelas, (Bandung: CV Wacana Prima, 2007) Hlm. 4.
} 
cukup untuk melakukan penelitian ini. Alasan memilih TPQ At-Tauhid dikarenakan santrisantri yang mulai mengikuti kegiatan mengaji adalah mulai berumur 3 Tahun yakni ketika anak-anak sudah mulai mampu berbicara orang tua mereka dengan segera mengikutsertakan anak-anaknya untuk mengaji.

\section{HASIL DAN PEMBAHASAN}

Sebelum melaksanakan penelitian terlebih dahulu dilaksanakan observasi pra tindakan gunanya untuk mengukur seberapa tingkat kemampuan membaca huruf hijaiyah santri di TPQ At-Tauhid Senori Tuban. Selain itu observasi pra tindakan dilakukan untuk mencari titik masalah, solusi yang akan digunakan serta metode yang akan diterapkan. Pra tindakan ini jugasebagai acuan berapa persen kemajuan yang ingin dicapai setelah diadakan penelitian. Dari observasi pra tindakan yang dilakukan didapat hasil seperti pada table dibawah ini:

Tabel 1. Kemampuan sebelum tindakan

\begin{tabular}{|c|c|c|c|c|c|}
\hline \multirow[t]{3}{*}{ No } & \multirow[t]{3}{*}{ Pernyataan/Aspek } & \multicolumn{4}{|c|}{ Prasiklus } \\
\hline & & \multicolumn{4}{|c|}{ Skor } \\
\hline & & 4 & 3 & 2 & 1 \\
\hline \multirow[t]{2}{*}{1} & $\begin{array}{l}\text { Menyebutkan } \\
\text { huruf hijaiyah }\end{array}$ & 6 & 9 & 10 & 8 \\
\hline & Prosentase & & & & \\
\hline \multirow[t]{2}{*}{2} & $\begin{array}{l}\text { Membedakan } \\
\text { harokat/tanda baca }\end{array}$ & 7 & 8 & 9 & 9 \\
\hline & Prosentase & & & & \\
\hline \multirow[t]{4}{*}{3} & $\begin{array}{l}\text { Membaca susunan huruf } \\
\text { menjadi kata }\end{array}$ & 8 & 10 & 8 & 9 \\
\hline & Prosentase & & & & \\
\hline & Jumlah & 21 & 27 & 27 & 26 \\
\hline & Prosentase & & & & \\
\hline
\end{tabular}

Berdasarkan table 1 diatas dapat dilihat aspek 1 sikap saat menyebutkan bunyi huruf Al-Qur'an memperoleh presentase $45 \%$ aspek 2 membedakan tanda baca/harokat memperoleh presentase sebesar 38\% dan aspek 3 membaca susunan huruf menjadi suku kata mendapat presentase sebesar $28 \%$.

Dari data tersebut dapat diambil rata-rata tingkat kemampuan membaca huruf hijaiyah santri TPQ At-Tauhid secara keseluruhan sebesar 40\%. Berdasarkan hasil tersebut peneliti beserta kolabolator sepakat penelitian dikatakan berhasil apabila rata-rata tingkat kemampuan membaca santri mencapai $65-80 \%$ 


\section{Siklus I}

a. Perencanaan. Sebelum melakukan penelitian, peneliti melakukan konsultasi dengan kolabolator dalam hal ini adalah guru yang mengajar di TPQ At-Tauhid untuk menyampaikan rencana akan akan dilaksanakan pada penelitian tindakan kelas. Peneliti juga meminta masukan dari kolabolator menilai persiapan yang dilakukan oleh peneliti sudah cukup baik.

b. Pelaksanaan tindakan kelas siklus Idilaksanakan 3 kali pertemuan dengan indicator yang sama yaitu menyebutkan bunyi huruf hijaiyah, membedakan harokah/tanda baca. Dan membaca susunan huruf menjadi suku kata. Penerapan metode yanbu'a digunakan yaitu dengan 2 cara, pertama dngan menggunakan puzzle huruf dan bernyanyi yang dipandu oleh guru dan cara yang ketiga dengan menggunakan kitab yanbu'a. wktu yang digunakan untuk penerapan metode yanbu'a sekitar 30 menit.

c. Pengamatan. Dari ketiga metode yanbu'a yang diterapjan, puzzle huruf dan menyanyi menjadi kegiatan yang paling efektif. Hal ini dikarenakan puzzle huruf dan menyanyi menarik perhatian santri sehingga dapat mengembalikan konsentrasi anak dalam pembelajaran membaca Al-Qur'an.

Tabel 2. Kemampuan membaca siklus I

\begin{tabular}{|c|c|c|c|c|c|}
\hline \multirow[t]{3}{*}{ No } & \multirow[t]{3}{*}{ Pernyataan/Aspek } & \multicolumn{4}{|c|}{ Prasiklus } \\
\hline & & \multicolumn{4}{|c|}{ Skor } \\
\hline & & 4 & 3 & 2 & 1 \\
\hline \multirow[t]{2}{*}{1} & $\begin{array}{l}\text { Menyebutkan } \\
\text { huruf hijaiyah }\end{array}$ & 11 & 9 & 7 & 6 \\
\hline & Prosentase & & & & \\
\hline \multirow[t]{2}{*}{2} & $\begin{array}{l}\text { Membedakan } \\
\text { harokat/tanda baca }\end{array}$ & 12 & 10 & 5 & 6 \\
\hline & Prosentase & & & & \\
\hline \multirow[t]{4}{*}{3} & $\begin{array}{l}\text { Membaca susunan huruf } \\
\text { menjadi kata }\end{array}$ & 12 & 11 & 5 & 5 \\
\hline & Prosentase & & & & \\
\hline & Jumlah & 35 & 30 & 17 & 17 \\
\hline & Prosentase & & & & \\
\hline
\end{tabular}

Berdasarkan table 2 diatas dapat dilihat aspek 1 sikap saat menyebutkan bunyi huruf Al-Qur'an memperoleh presentase 55\% aspek 2 membedakan tanda baca/harokat memperoleh presentase sebesar 50\% dan aspek 3 membaca susunan huruf menjadi suku kata mendapat presentase sebesar $49 \%$. 
Dari data tersebut dapat diambil rata-rata tingkat kemampuan membaca huruf hijaiyah santri TPQ At-Tauhid secara keseluruhan sebesar $50 \%$.

d. Refleksi. Tindakan refleksi ini membahas masalah yang muncul selama pelaksanaan penerapan metode yanbu'a dalam pembelajaran Al-Qur'an. Kemudian peneliti bersama kolabolator mendiskusikan langkah apa saja yang haru dilakukan untuk siklus II yang merupakan perbaikan dari Siklus I. beberapa masalah yang muncul antara lain: (1) Rentang waktu penerapan metode yanbu'a yang terlalu lama sehingga member kesempatan kepada santri untuk asyik ngobrol ataupun bermain sendiri. (2) materi pembelajaran membaca Al-Qur'an memerlukan konsentrasi penuh sehingga santri perlu media yang menarik. Sehingga dari kedua permasalahan tersebut peneliti bersama kolabolator mempersiapkan solusi yang akan dipakai dalam pelaksanaan siklus II, yaitu (1) Menetukan media dalam penerapan metodeyanbu'a yaitu dengan puzzle dan menyanyi dan menggunakan kitab yanbu'a. (2) memilih materi yang sesuai dengan tingkatan santri.

\section{Siklus II}

a. Perencanaan pada siklus II ini adalah mengevaluasi kekurangan-kekurangan yang tedapat pada siklus I diantaranya membuat rencana persiapan pembelajaran harian, menyiapkan materi dan metode yang digunakan dan menyiapkan kegiatan yang akan dijadiakn sumber data.

b. Pelaksanaan. Setiap pertemuan ada 3 kegiatan, dengan indicator yang sama seperti siklus I. penerapan yang diguanakan pada siklus II sepenuhnya dipandu oleh guru , dengan menggunakan puzzle, nyanyian dan kitab yanbu'a. penerapan metode yanbu'a dapat berjalan efektif. Santri kompak dalam mengikuti cara-cara metode yanbu'a yang diterapkan oleh guru sehingga dapat berjalan sesuai dengan rencana. Penerapan selanjutnya yaitu membaca kitab yanbu'a secara individual, yang kebanyakan santri sudah mempersiapkan diri untuk menunggu giliran membaca dengan kitab yanbu'a.

c. Pengamatan terhadap hasil. Materi yanbu'a yang digunakan siklus IIadalah membaca dengan puzzle dan nyanyian. Pada siklus IIdidapat rata-rata seperti table dibawah ini. 
Tabel 3. Kemampuan membaca pada sikulus II

\begin{tabular}{|c|c|c|c|c|c|}
\hline \multirow[t]{3}{*}{ No } & \multirow[t]{3}{*}{ Pernyataan/Aspek } & \multicolumn{4}{|c|}{ Prasiklus } \\
\hline & & \multicolumn{4}{|c|}{ Skor } \\
\hline & & 4 & 3 & 2 & 1 \\
\hline \multirow[t]{2}{*}{1} & $\begin{array}{l}\text { Menyebutkan } \quad \text { bunyi } \\
\text { huruf hijaiyah }\end{array}$ & 14 & 8 & 7 & 4 \\
\hline & Prosentase & & & & \\
\hline \multirow[t]{2}{*}{2} & $\begin{array}{l}\text { Membedakan } \\
\text { harokat/tanda baca }\end{array}$ & 14 & 9 & 6 & 4 \\
\hline & Prosentase & & & & \\
\hline \multirow[t]{4}{*}{3} & $\begin{array}{l}\text { Membaca susunan huruf } \\
\text { menjadi kata }\end{array}$ & 12 & 11 & 4 & 6 \\
\hline & Prosentase & & & & \\
\hline & Jumlah & 40 & 28 & 17 & 14 \\
\hline & Prosentase & & & & \\
\hline
\end{tabular}

Berdasarkan table 3 diatas dapat dilihat aspek 1 sikap saat menyebutkan bunyi huruf Al-Qur'an memperoleh presentase 73\% aspek 2 membedakan tanda baca/harokat memperoleh presentase sebesar $78 \%$ dan aspek 3 membaca susunan huruf menjadi suku kata mendapat presentase sebesar $75 \%$.

Dari data tersebut dapat diambil rata-rata tingkat kemampuan membaca huruf hijaiyah santri TPQ At-Tauhid secara keseluruhan sebesar 75\%.

d. Refleksi. Tindakan refleksi ini membahas masalah yang muncul selama pelaksaan tindakan siklus II. Dari hasil observasi diperoleh hasil:

1. Cara menerpkan metode yanbu'a yang efektif untuk meningkatkan kemampuan membaca Al-Qur'an

2. Metode yanbu'a yang efektif untuk meningkatkan kemampuan membaca AlQur'an santri sudah ditemukan

3. Criteria penilaian kemampuan membaca santri sudah hamper mencapai indicator yang ditentukan yakni $65 \%-80 \%$.

\section{KESIMPULAN}

Pada dasarnya metode yanbu'a dapat meningkatkan kemampuan membaca Al-Qur'an di TPQ At-Tauhid Leran Senori Tuban, terbukti dengan hasil yang telah dicapai oleh santri. Penggunanaan metode yanbu'a dilaksanakan selama 2 siklus 
dapat menanamkan kemampuan membaca huruf hijaiyah sebesar $34 \%$ dimulai dari pra tindakan prosentase kemampuan membaca menacapai $43 \%$ kemudian dialnajut siklus I naik menjaadi 55\%dan pada siklus II naik lagi menajdi 75\%. Adapun penanaman metode yanbu'a yang diterapkan di TPQ At-Tauhid dengan klasikal, individual dan sistem baca simakdan diperkuat dengan puzzle dan nyanyian karean berorientasi pada yanbu'a jilid pemula dan yanbu'a jilid 1 yang masih pada anak usia dini sehingga santri lebih mudah dan cepat menerima pembelajaran membaca huruf hijaiyah.

\section{DAFTAR PUSTAKA}

Abdurrahman, Drajat, Zakiyah, Ilmu Pendidikan Islam, Jakarta:Bumi Aksara,1996.

Venbriyanto , dkk, Kamus Pendidikan, Jakarta: Grafindo, 1996.

Ulin ,M. Nuha Arwani, Thariqh Baca Tulis dan Menghafal Al-Qur'an Yanbu'a Bimbingan cara mengajar,Kudus: Pondok Tahfidh Ynbu'ul Qur'an Kudus, 2009.

Arikunto, Suharsismi, dkk, Penelitian Tindakan Kelas, Jakarta: PT. Bumi Aksara, 2007.

Mohammad Asrori, Penelitian Tindakan Kelas, Bandung: CV Wacana Prima, 2007 